\title{
THE ROLE OF HISTORICAL-CULTURAL FORMATIONS WITHIN WORLD-SYSTEMS ANALYSIS: REFRAMING THE ANALYSIS OF BIOMEDICINE IN EAST AFRICA
}

\author{
David Baronov \\ Department of Sociology \\ St. John Fisher College \\ dbaronov@sjfc.edu
}

\begin{abstract}
This essay introduces a novel analytical concept for world-systems analysis, historical-cultural formations, for the purpose of analyzing reciprocal global cultural exchanges across the capitalist world-system. This is done through four basic procedures. First, the perspective of world-systems analysis is adopted for the purpose of analyzing biomedicine in world-historical context and biomedicine itself is re-conceptualized as a historical-cultural formation across a single capitalist world-system. Second, in order to conceptually incorporate historical-cultural formations, the basic analytical framework of world-systems analysis is expanded to include cultural forms as integral features of the capitalist world-system, parallel with economic and political structures. Third, biomedicine is framed as an ontological whole, comprised of multiple, embedded ontological spheres that define it as a dynamic cultural form subject to ongoing change and development. Fourth, biomedicine's journey to East Africa is framed as a facet of East Africa's incorporation into the capitalist world-system - a necessary prelude to the "globalization" of biomedicine as a historical-cultural formation. Ultimately, contemporary East African medical systems are discovered to be but the latest incarnation of an evolving, global biomedicine understood as a singular historical-cultural formation across the capitalist world-system.
\end{abstract}

\section{INTRODUCTION}

Given the accelerated pace and deepening patterns of contemporary political, economic and sociocultural interdependence, increasing attention has turned to the nature of global cultural exchanges over the past two decades, especially those between the core and periphery. Commonly, there is an interest in better understanding the impact of "Western" cultural influences on peripheral societies (i.e., modernization, Westernization). Unlike other global forms, such as the division of labor or commodity chains, however, global cultural forms are commonly thought to lack the formal structures and mechanisms that integrate the local and the global within a single process. Consequently, the unit of analysis tends to shift erratically between 
the local and the global level (Friedman 2000; Grosfoguel 2008). ${ }^{1}$ The result can be a type of cultural exchange reduced to direct, immediate contact that loses the basic insights of globalization as a collection of structures and processes that incorporate and transform societies and cultures in a fashion that simultaneously transforms these structures and processes. Hence, it is critical that the local/global dichotomy resolve itself within the details of a given historical episode and that the analysis of specific global cultural forms adopt a unit of analysis that conforms with the global context. By way of illustration, the early 20th-century journey of Western biomedicine to East Africa (specifically Kenya, Tanzania and Uganda) is considered here.

The challenge in this regard is to work within a reflexive framework that allows biomedicine to simultaneously transform East Africa as Africans transform biomedicine. Ultimately, the challenge is to identify an approach that allows one to turn from asking what the West can learn about Africans by studying their acclimation to biomedicine and to ask what the West can learn about Western medicine by understanding the African contributions to the development of biomedicine. World-systems analysis (WSA) offers clear advantages to this end, allowing one to simultaneously explore biomedicine as a culture-bound, historically-contingent social form while also analyzing biomedicine as an instrument of Western expansion. Indeed, as two of the leading proponents of WSA have argued, within the capitalist world-system, the cultural sphere represents a "third fundamental aspect" alongside and of equal rank with the domains of political and economic structures and processes.

There is a third fundamental aspect of the modern world-system, in addition to the specifically 'economic' aspect and the specifically 'political' aspect. That is the broadly 'cultural' aspect which needs to be mentioned even though little is systematically known about it as an integral aspect of world-historical development. (Hopkins and Wallerstein 1982:43)

Thus, WSA asks us to somehow faithfully capture the manifold history of biomedicine in East Africa while simultaneously placing these developments within the flow of historical structures and processes that constitute the capitalist world-system across a single, global unit of analysis, comprising a multiplicity of social times. Such work suggests a number of methodological challenges of considerable complexity. The analysis of any historical development, such as biomedicine in East Africa, emerges from an analysis of that development as a singular (and abstract) structure or process - the common starting point for inquiry in world-systems analysis (Bach 1982; Hopkins 1982a, 1982b; McMichael 1990). If biomedicine in East Africa is conceptualized as a singular process then what distinguishes it is not its external

${ }^{1}$ Comaroff and Comaroff (1993) frame this dilemma of global determinism versus local autonomy quite pointedly in the context of colonial and postcolonial Africa. "How do we write a historical anthropology of world systems that is not merely the History of the World System? Can we take sufficient account of the worldwide facts of colonial and postcolonial coercion, violence and exploitation, yet not slight the role of parochial signs and values, local meanings and historical sensibilities? How do we read European imperialism and its aftermath without reducing it to crude equations of power, domination and alienation?” (emphasis in original, Comaroff and Comaroff 1993:xiii). See also Appadurai (1995) in this regard. 
properties but its relationships to other structures and processes that comprise the capitalist worldsystem (e.g., colonialism in Africa). Procedurally, this entails an initial movement from more immediate abstract elements to the concrete whole (the capitalist world-system), such that the capitalist world-system and its constituent elements are mutually conditioning. ${ }^{2}$

To better capture phenomena across the cultural sphere as cardinal features of the capitalist world-system, the concept of "historical-cultural formation" is introduced here. In relation to the capitalist world-system, historical-cultural formations - such as biomedicine in East Africa - represent singular, abstract structures and processes. The term "historical-cultural" thus denotes a cultural formation that is dynamic, ever-developing and subject to change. Methodologically, one would be in error to treat these historical-cultural formations as discrete phenomena comprised of unique properties, such as the scientific method or germ theory, in an effort to draw comparisons with other historical-cultural formations. A historical-cultural formation's relation to the whole (its role as a constituent element) - as well as its relation to other historical-cultural formations - simultaneously defines that historical-cultural formation and further develops the capitalist world-system as a concrete whole. This would suggest that it is necessary to construct biomedicine in East Africa, as a historical-cultural formation, (1) in relation to the self-expanding capitalist world-system and (2) in relation to the ongoing structures and processes of Western expansion in East Africa. Similarly, one must not view biomedicine in East Africa, Western expansion, or the capitalist world-system as complete or fully-constituted absent these relationships. In this respect, consideration of historical-cultural formations is similar to that of economic and political structures and processes. Consequently, the intent here is to extend WSA in a fashion that treats biomedicine as a core-based, singular historical-cultural formation whose introduction to East Africa has been integral to the expansion of the capitalist world-system and to the further development of biomedicine itself.

\section{HISTORICAL-CULTURAL FORMATIONS AS CONSTITUENT ELEMENTS OF THE CAPITALIST WORLD-SYSTEM}

One of the most basic distinctions between historical-cultural formations and other elements of the capitalist world-system concerns their ontological status. Economic and political structures and processes are abstract expressions of the capitalist world-system whose analysis is, in part, an empirical question and, in part, a conceptual question. Biomedicine is a historical-cultural formation whose structures and processes, from one angle of vision, are also abstract expressions of the capitalist world-system. More immediately, however, biomedicine is an expression of collective social meaning. The study of historical-cultural formations differs for this reason from most of the work of WSA and suggests the need for additional analytical strategies-beyond the empirical and conceptual—-that permit interpretive methodological procedures.

As expressions of collective social meaning, the analysis of historical-cultural formations as constituent elements of the capitalist world-system introduces an ontological line of inquiry.

2 This formulation, of course, mirrors that described briefly by Marx in his passage from Grundrisse on "Method of Political Economy." Additionally, though developed in a different context, this emphasis on abstract parts in relation to a concrete whole is clearly influenced by the earlier works of Lefebvre (1968), Lukacs (1971) and Kosik (1976). 
Within WSA, the ontology of the division of labor (that which can be known about it) is essentially limited to the empirical-conceptual realm. As a historical-cultural formation, the ontology of biomedicine necessarily extends beyond the empirical-conceptual realm and includes the social worlds of interpretive communities. ${ }^{3}$ Indeed, as it develops, not only do biomedicine's empirical forms and conceptual roles within the capitalist world-system change, so too do its social meanings. Biomedicine, therefore, is comprised of multiple ontological spheres across empirical, interpretive and conceptual realms. But what types of phenomena, forms and categories constitute biomedicine as a subject for investigation across the ontological spheres? From an empirical perspective, biomedicine consists of concrete facts (truths) and objects that are observable and measurable. From an interpretive perspective, biomedicine is a symbolic-cultural expression that serves as a social representation whose meanings reify collective values and beliefs. From a conceptual perspective, biomedicine represents a social relation, a form of social organization that is itself a historical abstraction - an expression of underlying social power relations.

Each interpretation signals a unique set of ontological phenomena. Each reveals a particular facet of biomedicine and thus all are necessary for its full understanding. Privileging one facet above another would distort one's view and replace biomedicine, as a product of the dynamic interaction (and creative tension) between multiple ontological spheres, for a flat, threesided figure - a figure comprised of three discrete sides versus a figure constituted by the ongoing articulation of its manifold forms. Integrating these three ontological spheres necessarily results in a conceptual representation that sustains internal contradictions as a premise of its being. Thus, understood as an ontological whole, biomedicine is the product of multiple ontological spheres. Representations of biomedicine neglecting any one of these spheres will be distorted and one-sided. Representations incorporating all of these spheres will be contradictory and subject to constant revision. The task, therefore, is not to unite or reconcile these three spheres - biomedicine as an empirical object and biomedicine as a symbolic-cultural expression, for example, suggest alternative logics of inquiry. Rather, the task is to simultaneously develop each of these spheres as interdependent reflections of the multi-faceted nature of biomedicine, as a historical-cultural formation.

The multiple ontological spheres that comprise biomedicine each frame biomedicine as a distinct subject of investigation. From an empirical perspective, biomedicine takes on the appearance of a scientific enterprise and is defined as a derivative category of Western science more generally. As a scientific enterprise, biomedicine represents a combination of specialized knowledge, complex technology and scientific rigor and is subject to the critical scrutiny of liketrained, peer scientists. The image of biomedicine as a scientific enterprise is today ubiquitous. Most commonly, the life story of biomedicine is placed within the narrative of modern Western science, dating from the 16th century and roughly paralleling the duration of the capitalist worldsystem (Porter 1999; Shryock 1969; Wightman 1971). As an ontological sphere, therefore, biomedicine as a scientific enterprise details a rich world of complex medical-scientific

\footnotetext{
${ }^{3}$ The same could technically be said for economic and political structures and processes, such as the division of labor, and this remains a fertile area of investigation open to further inquiry. Within the WSA literature, the work of Wilma Dunaway (2001, 2008) and her analysis of households especially lends itself to this form of analysis.
} 
paraphernalia organized by the logic and rigor of a scientific-technical expertise. This would be a most welcome gift for Africa, no doubt.

From an interpretive perspective, biomedicine represents a symbolic-cultural expression whose avowed adherence to the principles of scientific objectivity conceals an ideological agenda (Gordon 1988; Kleinman 1993; Loustaunau and Sobo 1997). As a symbolic-cultural expression, biomedicine propagates a set of beliefs and values that reify a narrow and distorted (mis)understanding of health and medicine that attributes illness to "natural" conditions and, thereby, absolves the social environment. Biomedicine as a symbolic-cultural expression, stands in opposition to the first ontological sphere. That which distinguishes the second ontological sphere, therefore, is the shift from formal techniques promoting empirical explanations to a critique of biomedicine (and of science) that results in a process of inquiry grounded in interpretive understanding. From a conceptual perspective, biomedicine represents an expression of social power that reflects structures of class-based divisions in capitalist society. As an expression of social power, biomedicine is a type of social relation that links the parallel processes of the commodification of medicine and the concentration of power among biomedical practitioners with the historical structures and processes of capital accumulation that comprise the capitalist world-system (Brown 1979; Navarro 1976; Singer 1992). This third ontological sphere, therefore, concerns biomedicine's imbricated social relations and details both its rampant commodification and its calculated self-positioning vis-à-vis the realms of social power.

Biomedicine, therefore, framed as a historical-cultural formation and constituent element of the capitalist world-system is comprised of multiple, embedded ontological spheres. Capturing biomedicine as an ontological whole results from efforts to chart the ongoing interactions between the individual spheres that comprise biomedicine. This, indeed, is the nub of the challenge for WSA when addressing global cultural forms. The story of biomedicine in East Africa must, therefore, proceed with an understanding that it is these three spheres in unison that made the journey. To lay too great an emphasis on any one ontological sphere to the neglect of the others would be to distort biomedicine's development as a singular historical-cultural formation and to obscure East Africa's unique contributions to this process.

\section{BIOMEDICINE'S EAST AFRICAN JOURNEY}

The circumstances of biomedicine's arrival in East Africa provide the bases for its analysis. The period of the late 19th and early 20th century marked a dramatic period of territorial expansion for the capitalist world-system that prepared the path for biomedicine's African arrival. As such, the origins of biomedicine in East Africa interact on three spatial-temporal levels across a single, global unit of analysis. At the level of the capitalist world-system and the longue durée, biomedicine in East Africa marked a transformation of collective worldviews in concert with participation in the global division of labor and processes of capital accumulation. At the level of newly-incorporated East African territories and a middle-range episode, biomedicine was both a vital weapon against illness during conquest (e.g., "tropical medicine") as well as a putative ideological rationale for domination. At the level of the village and the short-term event, biomedicine provided colonial authorities with pragmatic solutions to a variety of dire health crises. It is precisely because biomedicine's arrival in East Africa took place across a single unit of analysis comprised of multiple social times that it must be treated as a singular historical- 
cultural formation whose development had implications at all three levels such that biomedicine transformed Africans as Africans transformed biomedicine.

Thus, the story of biomedicine's East African sojourn as a singular historical-cultural formation can be tracked along two trajectories. On the one hand, there was Europe's strategic introduction of biomedicine as a tool of colonial subjugation. ${ }^{4}$ Many, such as H. C. Trowell, a medical officer in colonial Kenya in 1935, were quite blunt in this regard. "[T]he combined forces of scientific invention, materialistic philosophy, philanthropic humanism, Christianity, education and economic enterprise are breaking down this primitive philosophy, and the greatest of these is the ruthless energy of modern economic enterprise which in every plantation, every market and every wayside stone is throttling out the life breath from the primitive philosophy of magic” (quoted in Beck 1970:139). In this way, biomedicine became one of the most powerful weapons for imposing Western cultural values, beliefs and practices on African peoples and, thereby, for furthering the colonial mission of conquest and economic exploitation. Emblematic in this regard were the series of large-scale, health campaigns in the first few decades of the 20th century prior to the development of an accessible dispensary system of medical care.

On the other hand, there was the East African adaptation of select aspects of biomedicine alongside the retention of many features of African pluralistic medicine. ${ }^{5}$ In the first half of the 20th century, though large segments of the African population had direct experience with biomedicine, it did not replace African pluralistic medicine as the preferred primary form of medicine. Instead, as they had done during previous encounters with Arabs, Indians and other African ethnic groups, East Africans borrowed liberally from that which they found of value and discarded the rest (Beck 1981; Good 1987; Swantz 1990). Consequently, both the European's strategic introduction and the East African's selective adaptation of biomedicine were premised on the simultaneous and fluid interpretations of biomedicine as a scientific enterprise, a symboliccultural expression and an expression of social power.

The actual introduction of biomedicine into colonial East Africa took place gradually and somewhat disjointedly over seven decades of British rule. ${ }^{6}$ Biomedicine was initially reserved for colonial officials and their local agents. Over time, however, a loose confederation of government dispensaries, medical missions and local pluralistic-medical practitioners (who were generally tolerated though not encouraged) combined to create an eclectic range of health care options for East Africans. In the first few decades of colonial rule, rural-based, medical missions were the primary source of contact with biomedicine for the vast majority of East Africans. Treatment was generally limited to particular medical conditions for which biomedicine had proven effective, such as yaws. Beginning in the 1920s, the colonial authorities began developing a system of rural dispensaries to reach the wider population and the primary medical priority remained curative

\footnotetext{
${ }^{4}$ See Arnold (1993), Lyons (1988a), MacLeod (1988), Porter (1999) and Worboys (2000).

5 The Western literature typically refers to African medical practices as "traditional" or "indigenous" medicine. Given that local African medical beliefs and practices invariably represented an eclectic admixture of a great many influences across various African societies, we prefer the term African pluralistic medicine. Practitioners are here referred to as pluralistic medical practitioners.

${ }^{6}$ See Gelfand (1976) for a description of parallel events in British-ruled Southern Rhodesia and Patterson (1981) for developments in Ghana.
} 
rather than broad-based preventive measures. ${ }^{7}$ This was, in part, due to a belief that the more immediate and visible nature of curative measures would more quickly hasten the African adoption of biomedicine than long-term, less dramatic preventive programs. Notwithstanding the occasional and lightly-enforced prohibitions, pluralistic-medical practices continued alongside biomedical services throughout the colonial period. Consequently, from a European perspective, biomedicine in East Africa evolved throughout the colonial era as a complementary form of medical care alongside - and never as a substitute for - African pluralistic medicine. Importantly, this contrasted with the African perspective, as Africans continued in pragmatic fashion to draw from a combination of medical beliefs and practices up to the time of independence. ${ }^{8}$

East Africa comprised three loosely integrated administrative units that were cobbled together over several decades of British trade and conquest. While many of the major health issues presented common challenges across all three colonies, with the exception of a brief unified health policy between 1903 and 1908, there was little effort to create a single, integrated medical system. Thus, despite overlapping health needs and policies, each colony administered its own health care system. Nonetheless, whether in Kenya, Uganda or Tanganyika it was well understood, especially in the early years, that the health of European soldiers, administrators and settlers was the top priority. The health of their African and Indian colonial agents was a secondary concern, while the health of all other Africans (especially those on the African reserves $^{9}$ ) was a distant third. For this reason, the thinly-scattered network of Christian missionary stations provided the vast majority of Africans with their first introduction to biomedicine. Mengo Hospital was a missionary hospital established by Dr. Albert Cook in Kampala in 1897. Along with Sewa Haji, a very poorly-resourced government hospital (see description below) built in Dar es Salaam in 1893, these were the only Western hospitals initially available to East Africans. ${ }^{10}$ By 1901, Mengo Hospital had 70 beds and treated 1,070 inpatients and 76,840 outpatients. As in most of colonial Africa, official segregation was imposed as a "health policy" to protect Europeans from possible disease (Marks and Andersson 1988). The disparities in medical care that resulted were stark. Between 1894 and 1919, there were never

\footnotetext{
${ }^{7}$ This mirrored the 19th-century public health campaigns in Europe that sought quick cures rather than more sweeping social reforms. "[In Kenya] (t)he government and physicians chose the cheap solution for delivering [medical] care. Rather than raising the living standards of the rural population (prevention), the colonial authorities tried to cure the population of yaws with injections of a drug of uncertain properties” (Dawson 1987:434).

${ }^{8}$ This was true throughout much of African. In the Ivory Coast, for example, Lasker observes that, "Western medicine was and continues to be one of a variety of therapeutic options used by Ivorians" (Lasker 1977:294).

9 The African reserves refers to a landholding system that primarily developed in Kenya. Colonial Kenya received far more settlers than Uganda or Tanganyika, especially after 1919. By 1920, Uganda had a European population of 350 (Hopwood 1980:148). Kenyan officials developed a reserve system whereby 31,000 square kilometers of prime land was set aside for European settlers. That land beyond these 31,000 square kilometers was referred to as the African reserves.

10 An Indian merchant, Sewa Haji, provided the funds for the hospital built in his name specifically to provide medical services to Africans, Indians and Arabs (Iliffe 2002:29).
} 
more than 25 doctors for three million Africans in Uganda (Hopwood 1980:147). ${ }^{11}$ A medical officer in Dar es Salaam just after WWI compared the hospital facilities available to Europeans with those set aside for Africans.

We have inherited from the Germans some medical buildings which compare favorably with any in Tropical Africa. The European Hospital, Dar es Salaam, is capable of accommodating fifty beds easily... It has a separate maternity section, well-fitted X-ray room and photographic dark room, and room for the examination of eye cases, spacious operating theatre, outpatient department and quarters for nursing staff and Medical Officer. It faces the Indian Ocean and receives the benefit of the sea breeze... At the other end of town near the Gerezani Creek is the Sewa Haji hospital for Indians and Natives, a curious rambling collection of buildings of which the administrative block is the outstanding feature. Its capacity is also about fifty beds, a number which is insufficient for the needs of a native town with a population estimated at twenty or twenty-five thousand, as well as for the K.A.R. Garrison, civil police, prisoners, railway and other Government Native and Indian employees. (Quoted in Ferguson 1979:326)

In the first few decades of colonial rule, medical missions were, therefore, the primary source of biomedicine for Africans in East Africa. ${ }^{12}$ "Medical missionary memoirs abound with stories of the early African dispensers, and the value of their work was readily recognized. In particular, they were the vanguard of the 'battle against superstition and witchcraft,' persuading recalcitrant patients and skeptics of the superiority of Western medicine” (Vaughn 1991b:65). ${ }^{13}$ Missionaries often found that even when many Africans rejected them as evangelizers there was still an interest in their medicine (Clyde 1980; Dawson 1987; Good 1987). It was invariably saving souls rather than relieving suffering that motivated mission medicine. In 1897, Archdeacon Walker of the Church Missionary Society in Mengo, Uganda declared that, "I regard the medical work from its missionary aspect... I consider how far it is likely to aid our work, not how much suffering will be relieved" (quoted in Ferguson 1979:319). While tacitly acknowledged by colonial officials as a critical supplementary resource, mission medicine was not a part of formal medical services. It was the Church Missionary Society hospital in Kampala, for example, that proved essential in the early diagnosis of the sleeping sickness epidemic in 1901.

The advances of tropical medicine in this era elsewhere in the world did not go unnoticed by colonial officials in East Africa and the period of 1900 to 1914 was a time of protracted health campaigns to combat the plague, malaria, sleeping sickness and, later, yaws. The growing European community in East Africa increasingly understood that health epidemics among Africans were very difficult to isolate and limit to the African population. At the same

${ }^{11}$ The medical budget for all of East Africa in 1900-1901 was 4,712 British pounds. This compared to a military budget of 38,005 British pounds for the same year (Beck 1970:14).

${ }^{12}$ See Beck (1970), Good (1987), Iliffe (2002) and Vaughn (1991).

${ }^{13}$ See Iliffe (2002:19-27) for a detailed overview of the various medical missions in East Africa at this time. 
time, in the case of certain epidemics, such as the plague, the links between disease and the deteriorating living conditions stemming from colonial rule were quite evident. ${ }^{14}$ Long endemic to Uganda, the plague made its first appearance in Nairobi in 1902 within the Indian community before spreading to other parts of Kenya. Plague, in fact, proved a continuing problem with further outbreaks in Nairobi in 1902, 1905, 1906, 1911, 1912 and 1913. The crowded and unsanitary conditions conducive to the plague were only exasperated by strictures of colonial rule. ${ }^{15}$ In Tanganyika, a sanitary authority modeled after the Gesundheitskommission in German cities was created in 1901 to address worsening conditions.

Many of the advances with regard to malaria were inspired by the 19th-century experiences of the British in India. By 1900, health officials certainly understood what needed to be done to alleviate the spread of malaria. Indeed, the celebrated Robert Koch visited East Africa three times between 1897 and 1907. However, given that malaria was not considered a major health threat to Europeans, efforts to control malaria in East Africa proceeded very slowly and with few resources. Additionally, due to scant public education, those anti-malarial measures that were taken were generally seen as yet another burden and many peasants adopted creative strategies to circumvent the new rules.

As with any regulations, individuals sought to evade them. In Tabora, for example, two years before Independence, the health officer stuck signposts into the ground in several parts of a wet valley. The signs proclaimed 'Cultivation is forbidden here.' In a few weeks' time, when the whole valley had become a sea of rice, the farmers were summoned to court where they indignantly stated that they had taken the greatest care to comply with the notices and had left at least an inch of ground uncultivated around each and every signpost. (Clyde 1980:102)

Sleeping sickness received much greater attention from colonial officials who were fearful of its potential for spread as far as India (Lyons 1988a). Mengo Hospital reported the first cases in February 1901 and within six months 200 persons had died. When the epidemic began, its cause and treatment presented a major medical mystery, though sleeping sickness itself was not new to the British, who first encountered sleeping sickness in 1734 in Guinea. By 1903, the cause had been traced to a Trypanosoma and the tsetse fly had been identified as its means of transmission to humans. Given that the number of tsetse flies numbered in the tens of millions in the vast Lake Victoria region, their eradication was considered all but impossible. Consequently, the only practical solution was to resettle large segments of the African population in areas far removed from the threat of sleeping sickness. A combination of limited resources and stagnant policy debates stalled action for several years until 1907 and an estimated 250,000 Africans perished in the interim (Duggan 1980:22). Like the European sanitation campaigns of the 19th century, the effort to relocate whole ethnic groups required both sympathetic persuasion and

${ }^{14}$ See Swanson (1979) for a discussion of similar efforts to combat the plague in South Africa in the early 20th century.

${ }^{15}$ In a similar fashion, Dawson (1979) suggests that in the case of the famine in central Kenya in 1897-1900 it was the social reaction to the famine — mass population movements into crowded areas with food - rather than malnutrition that left the population susceptible to the rapid spread of smallpox. See also Marks and Andersson (1988) and Turshen (1984) in this regard. 
paternalistic coercion (Lyons 1988b). Beck argues that this marked a shift in colonial attitudes toward the treatment of African populations. "In the brutal campaigns which accompanied the 'pacification' of certain areas, officials justified their disregard of human rights by the necessity of civilizing a district... Strange as it may sound, in the case of sleeping sickness, they felt at first that they could not justify compulsion” (Beck 1970:244). By 1908, almost everyone from the northern Uganda shoreline of Lake Victoria had been moved north.

Beginning in the 1930s, sleeping sickness policies reflected a genuine evolution in the relationship between Europeans and Africans. When there was a need to move people from Mwanza, a small village on the Tanganyikan side of Lake Victoria, the local population was allowed to participate in the selection of a re-location site. "[The villagers] asked in how many other countries [relocations] had been instituted to check disease and other dangers. If they were sure that the [relocations] would eventually extend everywhere, they would be agreeable and willing to do as the others had done. But, they said, they wanted only the place they chose” (Beck 1970:123). In the case of sleeping sickness and other epidemics, therefore, it was biomedicine as a scientific enterprise and as an expression of social power that most directly contributed to social transformation in the first few decades. Advances in identifying the etiology of "tropical" diseases pin-pointed the potential sources of infection and dictated the necessary measures to avoid these. Biomedicine at the service of the colonial mission determined how these medical campaigns would be carried out. Biomedicine as a symbolic-cultural expression, meanwhile, provided the general rationale for forcing compliance.

Unlike the slow and disappointing results from campaigns to control the plague, malaria and sleeping sickness, the yaws eradication campaign of the 1920s met with a great deal more initial success and the stricken East African population experienced rapid and dramatic improvement. Given this success, many believed that the yaws eradication campaign held much promise for a more profound impact on African attitudes toward biomedicine than the earlier health campaigns (Clyde 1980; Dawson 1987; Ranger 1981). The 1920s yaws eradication campaign was the first major health initiative targeting a disease exclusively impacting Africans. In addition, because the primary treatment involved an injection, the role of the syringe created a mystique of healing power that became associated with biomedicine as a symbolic-cultural expression. Medical officers explicitly viewed the yaws campaign as an opportunity to popularize biomedicine and turn Africans away from local traditions.

[T]he popularity of injections with the African population would forward the long-range goals of the [Medical] Department. [J. L.] Gilks (Kenya's principle medical officer) and others felt that the anti-yaws therapy would show the population the value of Western biomedicine and turn them away from using 'native medicine and witchcraft.' They also believed that the clinical success of the anti-yaws campaigns would both make the administration of rural reserves easier and make other public health campaigns more popular. (Dawson 1987:420-421) 
Prior to WWI, medical missions were the primary source of biomedical care for yaws. ${ }^{16}$ In southern Tanganyika, for example, large camps sprang up around medical missions in Masasi and Luatala. “'The hospital at Luatala is a wonderful sight,' wrote Miss Andrews (a mission nurse) in July (1914), 'a great camp of some 220 people and 50 or 60 little fires at night'” (quoted in Ranger, 1981:266). Beginning in 1920, colonial authorities initiated a formal yaws eradication campaign based on the system developed by the Church of Scotland mission at Tumutumu in Central Kenya. A series of satellite dispensaries staffed by African dressers were built around a central hospital with European physicians and nurses. This was a prelude to the rural-based dispensary system that became the backbone of colonial medical services for most East Africans through the 1940s.

Initial reticence for injections was overcome by the positive results and the demand for treatment grew exponentially as sprawling campgrounds began to sprout up along the edges of medical stations. Between 1920 and 1931, 712,228 Africans were treated in Kenya alone (Dawson 1987:425). ${ }^{17}$ By 1929, another 500,000 plus had been treated in Tanganyika (Clyde 1980:104). Given the novelty of the treatment mode, an injection, tremendous faith was placed in the healing power of the syringe. Ranger interprets African reverence for injection-based treatments as an extension of local healing traditions. "The fame of the needle - sindano spread far and wide; people came for very long distances; and so soon as a dispensary was opened in a new part of the district there were at once crowds of yaws patients. The atmosphere was very clearly that of the spontaneous and intense movements of mass cleansing” (Ranger 1981:266). The popularity of the injection-based 1920s yaws eradication campaign contrasts sharply with the occasional smallpox vaccination campaigns prior to 1920 that encountered skepticism and hostility. Rather than leading to popular demands for treatment, the smallpox campaigns relied upon force and coercion (Dawson 1987:432). ${ }^{18}$ Both Clyde (1980) and Dawson (1987) argue that the 1920s anti-yaws campaign created the first significant public demand for biomedicine in East Africa. "Despite the broadening of health-care measures in the early decades of this century, it took the dramatically effective campaign against the widespread and crippling disease of yaws to engender public demand rather than, at best, passive acceptance" (Clyde 1980:103).

Alternatively, Ranger (1981) suggests that the nature of the medical care that Africans experienced fit well within the established African tradition of 'indigenous healing cults.' "In its intensity, its periodic and spasmodic character, and in its isolation from general notions of misfortune and healing, the movement of yaws victims to the mission clinics resembled nothing so much as an indigenous healing cult, of which there had been a succession in [the Masasi region of southeast Tanzania]" (Ranger 1981:265). Because of the complementary nature of biomedicine with certain local African practices, Ranger argues that the yaws eradication campaign ultimately

${ }^{16}$ Primarily a childhood disease found in rural, tropical areas with poor sanitation, yaws progresses from a primary lesion to secondary infections and relapsing skin eruptions.

${ }_{17}$ This reflects only the number of persons treated at government facilities and does not record the number treated at mission sites.

${ }^{18}$ See Arnold (1988) for a discussion of parallel British efforts to control smallpox in colonial India. 
led to only a negligible number of African converts to Western medical practices. ${ }^{19}$ Rather, following the yaws eradication campaign, a resilient and pragmatic attitude prevailed in which biomedicine was seen as appropriate for certain afflictions and local pluralistic-medicine for others (Orley 1980; Ranger 1981). ${ }^{20}$

These views reflected a more general African sentiment regarding the utility of biomedicine. At one level, there was a general acceptance of biomedical practices for certain diseases. This was based on practical, empirical experience. As patients improved, community skepticism waned and biomedical beliefs and practices were accepted and found compatible with local collective worldviews. At the same time, given the failure of biomedicine to treat other illnesses it was naturally concluded that biomedicine was inadequate for other medical conditions. This was, in part, a simple matter of contrasting etiological frameworks. As was freely conceded by colonial officials, biomedical treatments were restricted to those diseases with causes found in the natural world. Insofar as biomedicine was useless to treat those afflicted by diseases linked to the supernatural or social worlds, it was accepted by East Africans within these limitations.

It was precisely due to biomedicine's status as a historical-cultural formation comprised of multiple ontological spheres that allowed the West to fashion it so effectively as a tool of colonization during this period of expansion for the capitalist world-system in East Africa. Biomedicine as a scientific enterprise lent credibility to the medical claims of biomedicine and secured African cooperation during its campaigns to combat plague, malaria, sleeping sickness and yaws. That specific remedies led to specific cures provided an opening first for biomedicine and then for Western advances more generally. Biomedicine as a symbolic-cultural expression was pragmatically grafted onto varying forms of African pluralistic medicine. While Europeans viewed biomedicine and African pluralistic medicine as wholly incompatible, Africans generally viewed biomedicine as offering certain insights and practices that could be readily incorporated into African pluralistic medicine. Biomedicine as an expression of social power proved fully transparent whether in the hands of colonial administrators or of Christian missionaries. At the same time, the role of African pluralistic medical practitioners in fomenting African resistance (see below) made equally evident the central role of African pluralistic medicine as an expression of social power. In this manner, biomedicine and African pluralistic medicine competed as historical-cultural formations not only as medical interventions but as alternative cosmologies

19 There were, likewise, few conversions to Christianity resulting from yaws treatment, as reflected in a mission doctor's lament. "Dr. Taylor wrote in 1929 'from the missionary point of view this part of our work (yaws treatment) at first sight seems of very little direct value, for the patients rarely stop long and often come from great distances, so that it is useless to try to teach them the Faith'” (Ranger 1981:267). See also Ranger (1988) for a similar analysis of the 1918 flu epidemic in Southern Rhodesia. "[T]he pandemic of 1918 with its atmosphere of crisis and with the effective failure of all medical treatment, powerfully assisted and legitimated the emergence of African anti-medicine” (Ranger 1988:186).

${ }^{20}$ Patterson (1981) documents similar attitudes and practices in colonial Ghana. "Many people took an eclectic approach, seeking the best elements of various medical systems. Advised or directed by family and friends, they might consult a colonial physician and a local practitioner simultaneously or, more likely, go to the clinic after the village healer had failed" (Patterson 1981:28). 
shaping collective worldviews. The survival of African pluralistic medicine to the present day, in fact, represents a powerful and ongoing anti-systemic movement within the capitalist worldsystem.

Importantly, throughout the colonial era, pluralistic medicine remained a pivotal sociocultural institution across East Africa, shaping health beliefs and practices. Pluralisticmedical practitioners (referred to variously by Westerners as witch doctors, sorcerers, medicine men, diviners, etc.) predominated in the rural hinterland and were generally ignored by colonial officials so long as they were not perceived to interfere with colonial rule (Iliffe 2002).

[T]he medical department - interested primarily in the good will of Africans living in the few urbanized centers - did not care to inquire into the living habits of the vast masses of the rural population. Therefore, the African traditional healer was left alone to exercise an important function of healing among his own people. (Beck 1981:62)

While most pluralistic-medical practitioners were content to quietly persist in their remote work, many also assumed key roles in fomenting and organizing anti-colonial struggle. Indeed, the role of pluralistic-medical practitioners as instigators and leaders during popular insurrections - often acting as popular priests and spirit mediums - presented colonial authorities with some of their most serious challenges.

In Kenya, where the Kitombo movement of 1896 was followed by the Kathambi movement - named after the female Kamba water-spirit - in 1910, colonial officials reported that, "The new types of possessing spirits and frenzied dances, drumming and promise of deliverance associated with these cults served to focus Kamba frustrations and their opposition to colonial rule” (Good 1987:80). Also in Kenya, the Mumbo religious leader, Onyango Dande, led a revolt in 1913 and the Akamba priestess, Siofume, led a rebellion in eastern Kenya in 1911. In 1905, the prophet, Kinjikitile Ngwale, led one of the largest African revolts, the Maji Maji rebellion to drive the Germans out of Tanganyika. Over 75,000 Africans were slaughtered in this rebellion alone. It was evident to colonial officials that the position of pluralistic-medical practitioners as interpreters of — and mediators within - the broader African cosmological order granted them considerable power and influence. Consequently, biomedicine and African pluralistic medicine knew one another from their first encounter as both ideological and political enemies. $^{21}$

It followed that, at least for a period, the colonial authorities felt compelled to tolerate pluralistic-medical practitioners and a pragmatic balance of biomedicine and local medical practices remained a cardinal feature of rural life. British officials combined this attitude of indifference toward policing local healing practices with a pernicious belittling of local beliefs and customs. The prohibitions against female circumcision were rarely enforced and the witchcraft ordinances of 1909, 1918 and 1925 did not lead to any major effort to police the activities of pluralistic-medical practitioners. Thus, unlike other parts of colonial Africa, such as the Belgian Congo, in East Africa there was little systematic effort to prohibit the practice of pluralistic medicine. In fact, many colonial officials developed an appreciation for such practices and endeavored to better understand the underlying cosmology that organized African life. For

${ }^{21}$ See Fanon (1965, 1967), Levy (1978), Onoge (1975), Paul (1979) and Turshen (1984). 
example, a 1929 Tanganyikan witchcraft ordinance distinguished between the exercise of benevolent magic (uchawi) and the practice of malevolent magic (uganga). While the line between uchawi and uganga was not always precise, the attempt to draw such distinctions, nonetheless, suggests that colonial officials recognized differences among the pluralistic-medical practitioners whose key social role was undeniable.

At the same time, the European colonial powers brought with them an unshakeable faith in those modern scientific principles born of the Western Enlightenment and the colonial order they established in Africa was, in part, premised upon the promulgation of, and a respect for, these basic principles. Thus, when an illness was attributed to supernatural forces and a pluralistic-medical practitioner was consulted to interpret the origin of the problem, the colonial authorities labored to frame these beliefs and practices within a familiar set of epistemological premises. From this encounter emerged a number of crude dichotomies intended to distinguish between European and African mindsets; e.g., modern/primitive, logical/illogical, rational/ irrational, civilized/uncivilized, backward/progressive. Colonial officials in East Africa generally thought of pluralistic-medical practices as combining rational and irrational elements and this was dutifully confirmed by legions of Western anthropologists throughout the colonial era. L. F. Gerlach, a British anthropologist, represents a case in point with his study of the health practices of the Digo from northern Tanganyika.

In a study on the Digo of East Africa, Gerlach concerned himself with the contradiction of logical conclusions and magic in his presentation of Digo conceptions of health and disease. Diagnosis, he wrote, proceeded in a logical manner, but it was based on the unscientific Digo premises as to the cause and effect of illness. The fact that logical conclusions were drawn from non-logical and non-verifiable assumptions caused many misinterpretations of the relationship between magic and natural treatment in traditional medicine. (Beck 1981:68)

Of course, the purpose of such anthropological work was not greater cultural understanding between peoples. The ethnographic goal was to wield cultural sensitivity as a weapon of subjugation, whereby one culture could subsume another. ${ }^{22}$ In this regard, the colonial authority's relentless rhetorical demonizing of African pluralistic medicine invariably framed European cultural values and rationalist traditions in even starker relief. Through its depictions of biomedicine as "scientific" and African pluralistic medicine as "primitive" it was made clear to Africans that the continued practice of pluralistic medicine was a sign of shameful backwardness. ${ }^{23}$

With respect to African pluralistic medicine, the colonial project embodied a difficult tension, balancing both its civilizing mission (the introduction of Western, scientific medicine) and its need for stable governance (the appeasement of local populations). Overturning longstanding cultural practices and social institutions wholesale was rarely conducive to pacification. However, perpetuating local customs that were an anathema to the colonizer's understanding of

${ }^{22}$ See Baronov (2004) for a contemporary example regarding public health educators in Puerto Rico and US-sponsored HIV/AIDS prevention campaigns.

${ }^{23}$ See Fanon (1965, 1967), Good (1987), Memmi (1965) and Vaughn (1994). 
the world would merely sustain an unbridgeable gulf between European and African. Most Europeans assumed that, ultimately, the steady advance of biomedicine in East Africa would invariably erode the influence of local cultural beliefs and practices (Beck 1970; Good 1987; Olumwullah 2002). Judging by the strong retention of pluralistic-medical beliefs and practices throughout the colonial era, such notions clearly proved mistaken. At the same time, whatever their competencies in the realm of medicine, colonial medical officials were hardly trained or qualified to negotiate the breach between the sacrosanct traditions of the Western Enlightenment and East African collective worldviews. Conflicts over female circumcision and the link between these conflicts and the rise of Kenyan nationalism, for example, were well beyond the expertise of medical officials. Furthermore, given the danger of violent rebellion - and the central role of pluralistic-medical practitioners in this regard - such issues were clearly as much political concerns as medical matters.

Thus, biomedicine's dramatic advances across East Africa notwithstanding, African pluralistic medicine ultimately survived and generally thrived throughout the era of colonial rule and this continued after independence. "[Pluralistic medicine] was an aspect of African life that had not been eliminated by the building of roads, ports, railways and a few cities in Kenya and Tanzania. Even dispensaries operated in the bush by young African helpers coexisted with the traditional healer" (Beck 1981:70). Many independence leaders, however, considered biomedicine to be integral to progress and development and, in the period just after independence, pluralistic medicine was not an area of major interest for governments. It was beginning with the Arusha Declaration in 1967, and its call for the mobilization of all available national resources, that pluralistic medicine came to be seen as a valuable asset in Tanzania and elsewhere to assist development - especially given the dire shortage of rural medical staff (Harrison 1974; Janzen 1976/77; Oyeneye 1985). By the 1970s, there was a growing international awareness of the need for peripheral societies, such as Uganda, Kenya and Tanzania, to make greater use of pluralisticmedicine and a mounting skepticism towards an over-reliance on capital-intensive, high-tech medicine (Baer, Singer and Susser 2003; Thomas 1975).

Today, African pluralistic medicine and biomedicine continue to survive side-by-side in East Africa, notwithstanding the relatively scant resources available for the latter. In point of fact, over time, it is biomedicine that has been absorbed into African pluralistic medicine and not vice versa. Because biomedicine narrowly limits disease etiology to factors in the natural world it is unable to account for African pluralistic medical explanations tied to the supernatural or social worlds. However, insofar as African pluralistic medicine has a long history of relying on medical explanations and treatments based on explanations in the natural world (e.g., the use of botanicals), African pluralistic medical practitioners exhibit little difficulty in adopting a number of biomedical practices. The result, in East Africa, has been the African transformation of biomedicine as a historical-cultural formation that is compatible with African pluralistic medicine. This transformation is only possible given the premise of biomedicine as comprised of multiple ontological spheres. As a scientific enterprise, biomedical etiological premises are largely compatible with aspects of African pluralistic medicine. As a symbolic-cultural expression and as an expression of social power, African pluralistic medicine was able to largely co-opt and absorb biomedicine. In the process, biomedicine as a singular historical-cultural formation across the capitalist world-system was appropriated by Africans and accordingly reconstituted - as an appendage of African pluralistic medicine - to better meet their needs. 


\section{CONCLUSION}

The journey of biomedicine to East Africa served as an extension of European conquest and colonial rule over the African continent and signaled a moment in the incorporation of East Africa into the capitalist world-system. After reaching the African shore as a singular historicalcultural formation, biomedicine invariably pulled East Africa more and more tightly into the orbit of those economic, political and historical-cultural structures and processes that comprise the capitalist world-system. It is argued here that historical-cultural formations, such as biomedicine, are, in fact, no less essential elements of the capitalist world-system than economic and political structures. Expanding WSA to include historical-cultural formations is thus a necessary step in presenting a more complete picture of the capitalist world-system conceptually and, thereby, enhancing our understanding of the reciprocal global cultural exchanges that comprise the capitalist world-system more generally.

Contemporary East African medical systems, for example, are the products of ongoing historical-cultural exchanges between Western biomedicine and African pluralistic medicine, as shaped by the development of the historical structures and processes that comprise the capitalist world-system. The unique features of these East African medical systems reinforce the prominence of local influences over global influences in shaping medical systems and represent East Africa's re-interpretation and enduring transformation of biomedicine as a historical-cultural formation at the global level. From an African perspective, after all, the story of biomedicine in East Africa concerns how Africans borrowed select elements from a provincial European medical tradition which allowed them to, thereby, deepen and further develop their own African medical practices. For East Africa, it was not a matter of the universalization of biomedicine at the expense of African pluralistic medicine. It was a matter of "particularizing" biomedicine to permit its appropriation by Africans. Ultimately, the capacity of biomedicine to transform East Africa and of Africans to transform biomedicine fundamentally turned on its ontological status as a singular historical-cultural formation and constituent element of the capitalist world-system.

\section{REFERENCES}

Appadurai, Arjun. 1995. “The Production of Locality.” Pp. 204-225 in Counterworks: Managing the Diversity of Knowledge, edited by Richard Fardon. New York: Routledge Press.

Arnold, David. 1993. "Medicine and Colonialism.” Pp. 1393-1416 in Companion Encyclopedia of the History of Medicine, Volume II, edited by W. F. Bynum and Roy Porter. London: Routledge.

1988. "Smallpox and Colonial Medicine in Nineteenth-Century India." Pp. 45-65 in Imperial Medicine and Indigenous Societies, edited by David Arnold. Manchester: Manchester University Press.

Bach, Robert. 1982. "On the Holism of a World-System Perspective.” Pp. 159-180 in WorldSystems Analysis: Theory and Methodology, edited by Terence Hopkins and Immanuel Wallerstein. Beverly Hills, CA: Sage.

Baer, Hans A., Merrill Singer and Ida Susser. 2003. "Biomedical Hegemony in the Context of Medical Pluralism.” Pp. 329-352 in Medical Anthropology and the World System, 2nd Edition, edited by Hans A. Baer, Merrill Singer and Ida Susser. Westport, CT: Praeger. 
Baronov, David. 2004 "Exporting Behavior Modification Models to a US Colony: Public Health Workers and HIV/AIDS Prevention in Puerto Rico.” Caribbean Studies. 32(2):105-44.

Beck, Ann. 1970. A History of the British Medical Administration of East Africa. Cambridge, MA: Harvard University Press. 1981. Medicine, Tradition and Development in Kenya and Tanzania, 1920-1970. Waltham, MA: Crossroads Press.

Brown, E. Richard. 1979. Rockefeller Medicine Men: Medicine and Capitalism in America. Berkeley, CA: University of California Press.

Clyde, David. 1980. “Tanzania.” Pp. 98-113 in Health in Tropical Africa During the Colonial Period, edited by E. Sabben-Clare, D. Bradley and K. Kirkwood. Oxford, UK: Clarendon Press.

Comaroff, Jean and John Comaroff. 1993. "Introduction.” Pp. xi-xxxvii in Modernity and Its Malcontents: Ritual and Power in Postcolonial Africa, edited by Jean Comaroff and John Comaroff. Chicago, IL: University of Chicago Press.

Dawson, Marc. 1987. "The Anti-Yaws Campaign and Colonial Medical Policy in Kenya." International Journal of African Historical Studies. 20:417-37.

. 1979. "Smallpox Vaccine in Kenya, 1880-1920.” Social Science and Medicine. 13B:24551.

Duggan, A. 1980. “Sleeping Sickness Epidemics.” Pp. 19-29 in Health in Tropical Africa During the Colonial Period, edited by E. Sabben-Clare, D. Bradley and K. Kirkwood. Oxford: Clarendon Press.

Dunaway, Wilma. 2008. Women, Work and Family in the Antebellum Mountain South. London: Cambridge University Press.

. 2001. "The Double Register of History: Situating the Forgotten Woman and Her Household in Capitalist Commodity Chains.” Journal of World-System Research 7 (1).

Fanon, Frantz. 1967. "Medicine and Colonialism.” Pp. 121-45 in A Dying Colonialism. New York: Grove Press.

1965. The Wretched of the Earth. New York: Grove Press.

Ferguson, D. 1979. “The Political Economy of Health and Medicine in Colonial Tanganyika.” Pp. 307-343 in Tanzania Under Colonial Rule, edited by M. Kaniki. London: Longman Group Limited.

Friedman, Jonathon. 2000. "Globalization, Class and Culture in Global Systems." Journal of World-System Research. 6(3):636-656.

Gelfand, Michael. 1976. A Service to the Sick: A History of the Health Services for Africans in Southern Rhodesia (1890-1953). Gwelo: Mambo Press.

Good, Charles. 1987. Ethnomedical Systems in Africa: Patterns of Traditional Medicine in Rural and Urban Kenya. New York: Guilford Press.

Gordon, Deborah. 1988. “Tenacious Assumptions in Western Medicine.” Pp. 19-56 in Biomedicine Reconsidered, edited by Margaret Lock and Deborah Gordon. Dordrecht: Kluwer Academic Publishers.

Grosfoguel, Ramón. 2008. "World-Systems Analysis and Postcolonial Studies: A Call for a Dialogue from the 'Coloniality of Power' Perspective.” Pp. 94-104 in The Postcolonial and the Global, edited by Revathi Krishnaswamy and John Hawley. Minneapolis: University of Minnesota Press. 
Harrison, Ira. 1974. "Traditional Healers: A Neglected Source of Health Manpower.” Rural Africana. 26(1):5-16.

Hopkins, Terence. 1982a. "The Study of the Capitalist World-Economy: Some Introductory Considerations.” Pp. 9-38 in World-Systems Analysis: Theory and Methodology, edited by Terence Hopkins and Immanuel Wallerstein. Beverly Hills, CA: Sage.

1982b. "World-Systems Analysis: Methodological Issues.” Pp. 145-158 in World-Systems Analysis: Theory and Methodology, edited by Terence Hopkins and Immanuel Wallerstein. Beverly Hills, CA: Sage.

Hopkins, Terence and Immanuel Wallerstein. 1982. "Patterns of Development of the Modern World-System.” Pp. 41-82 in World-Systems Analysis: Theory and Methodology, edited by Terence Hopkins and Immanuel Wallerstein. Beverly Hills, CA: Sage.

Hopwood, B. 1980. "Primary Health Care in Uganda, 1894-1962." Pp. 147-157 in Health in Tropical Africa During the Colonial Period, edited by E. Sabben-Clare, D. Bradley and K. Kirkwood. Oxford: Clarendon Press.

Iliffe, John. 2002. East African Doctors: A History of the Modern Profession. Kampala, Uganda: Fountain Publishers.

Janzen, John. 1976/77. "Traditional Medicine Now Seen as National Resource in Zaire and Other African Countries.” Ethnomedizin. IV(1/2):167-70.

Kleinman, Arthur. 1993. "What is Specific to Western Medicine?" Pp. 15-23 in Companion Encyclopedia for the History of Medicine, Volume I, edited by W. Bynum and Roy Porter. New York: Routledge.

Kosik, Karel. 1976. Dialectics of the Concrete: A Study of Problems of Man and World. Dordrecht, Holland: D. Reidel Publishing Company.

Lasker, Judith. 1977. "The Role of Health Service in Colonial Rule: The Case of the Ivory Coast.” Culture, Medicine and Psychiatry. 1:277-97.

Lefebvre, Henri. 1968 [1940]. Dialectical Materialism. Translated by John Sturrock. London: Jonathon Cape LTD.

Levy, Howard. 1978. “The Military Medicinemen.” Pp. 287-300 in The Cultural Crisis of Modern Medicine, edited by John Ehrenreich. New York: Monthly Review Press.

Loustaunau, Martha and Elisa Sobo. 1997. The Cultural Context of Health, Illness and Medicine. Westport, CT: Bergin \& Garvey.

Lukacs, Georg. (1971 [1923]. History and Class Consciousness. Cambridge, MA: MIT Press.

Lyons, Maryinez. 1988a. "Sleeping Sickness, Colonial Medicine and Imperialism: Some Connections in the Belgian Congo.” Pp. 242-256 in Disease, Medicine and Empire: Perspectives on Western Medicine and the Experience of European Expansion, edited by Roy MacLeod and Milton Lewis. New York: Routledge.

1988b. "Sleeping Sickness Epidemics and Public Health in the Belgian Congo.” Pp. 105124 in Imperial Medicine and Indigenous Societies, edited by David Arnold. Manchester: Manchester University Press.

MacLeod, Roy. 1988. "Introduction.” Pp. 1-18 in Disease, Medicine and Empire: Perspectives on Western Medicine and the Experience of European Expansion, edited by Roy MacLeod and Milton Lewis. New York: Routledge.

Marks, Shula and Neil Andersson. 1988. "Typhus and Social Control: South Africa, 1917-1950.” Pp. 257-283 in Disease, Medicine and Empire: Perspectives on Western Medicine and 
the Experience of European Expansion, edited by Roy MacLeod and Milton Lewis. New York: Routledge.

McMichael, Philip. 1990. "Incorporating Comparison Within a World-Historical Perspective: An Alternative Comparative Method.” American Sociological Review. 55(3):385-397.

Memmi, Albert. 1965. The Colonizer and the Colonized. Boston: Beacon Press

Navarro, Vicente. 1976. Medicine Under Capitalism. New York: Prodist.

Olumwullah, Osaak. 2002. Dis-Ease in the Colonial State. Westport, CT: Greenwood Press.

Onoge, Omafume. 1975. "Capitalism and Public Health: A Neglected Theme in the Medical Anthropology of Africa.” Pp. 219-232 in Topias and Utopias in Health: Policy Studies, edited by Stanley Ingman and Anthony Thomas. The Hague: Mouton Publishers.

Orley, John. 1980. "Indigenous Concepts of Disease and Their Interaction with Scientific Medicine.” Pp. 127-134 in Health in Tropical Africa During the Colonial Period, edited by E. Sabben-Clare, D. Bradley and K. Kirkwood. Oxford: Clarendon Press.

Oyeneye, O. 1985. "Mobilizing Indigenous Resources for Primary Health Care in Nigeria: A Note on the Place of Traditional Medicine." Social Science and Medicine. 20:67-69.

Paul, James. 1979. "Medicine and Imperialism.” Pp. 271-86 in The Cultural Crisis of Modern Medicine, edited by John Ehrenreich. New York: Monthly Review Press.

Patterson, David. 1981. Health in Colonial Ghana: Disease, Medicine and Socio-Economic Change, 1900-1955. Waltham, MA: Crossroads Press.

Porter, Roy. 1999. The Greatest Benefit to Mankind: A Medical History of Mankind. New York: W.W. Norton.

Ranger, Terence. 1988. "The Influenza Pandemic in Southern Rhodesia: A Crisis of Comprehension.” Pp. 172-188 in Imperial Medicine and Indigenous Societies, edited by David Arnold. Manchester: Manchester University Press.

. 1981. "Godly Medicine: The Ambiguities of Medical Mission in Southeast Tanzania." Social Science and Medicine. 15B:261-77.

Shryock, Richard. 1969. The Development of Modern Medicine: An Interpretation of the Social and Scientific Factors Involved. New York: Hafner Publishing Company.

Singer, Merrill. 1992. "Biomedicine and the Political Economy of Science." Medical Anthropology Quarterly. 6(4):400-403.

Swanson, Maynard. 1979. "The Sanitation Syndrome: Bubonic Plague and Urban Native Policy in Cape Colony, 1900-1909.” Journal of African History. 18(3):387-410.

Swantz, Lloyd. 1990. The Medicine Man Among the Zaramo of Dar es Salaam. Uddevalla, Sweden: Scandinavian Institute of African Studies.

Thomas, Anthony. 1975. "Healthcare in Ukambani Kenya: A Socialist Critique.” Pp. 267-282 in Topias and Utopias in Health: Policy Studies, edited by Stanley Ingman and Anthony Thomas. The Hague: Mouton Publishers.

Turshen, Meredith. 1984. The Political Ecology of Disease in Tanzania. New Brunswick, NJ: Rutgers University Press.

Vaughan, Megan. 1994. "Health and Hegemony: Representation of Disease and the Creation of the Colonial Subject in Nyasaland.” Pp. 173-201 in Contesting Colonial Hegemony: State and Society in Africa and India, edited by Dagmar Engels and Shula Marks. London: British Academic Press.

1991. Curing Their Ills: Colonial Power and African Illness. Stanford, CA: Stanford University Press. 
Wightman, W. 1971. The Emergence of Scientific Medicine. Edinburgh: Oliver and Boyd. Worboys, Michael. 2000. “Colonial Medicine.” Pp. 67-80 in Medicine in the Twentieth Century, edited by Roger Cooter and John Pickstone. Amsterdam: Harwood Academic Publishers. 